\title{
Survivorship and feeding preferences among size classes of outplanted sea urchins, Tripneustes gratilla, and possible use as biocontrol for invasive alien algae
}

Charley E Westbrook, Rory R Ringang, Sean Michael A. Cantero, HDAR \& TNC Urchin Team, Robert J Toonen

We investigate the survivorship, growth and diet preferences of hatchery-raised juvenile urchins, Tripneustes gratilla, to evaluate the efficacy of their use as biocontrol agents in the efforts to reduce alien invasive algae. In flow through tanks, we measured urchin growth rates, feeding rates and feeding preferences among diets of the most common invasive algae found in Kāne'ohe Bay, Hawai'i: Acanthophora spicifera, Gracilaria salicornia, Eucheuma denticulatum and Kappaphycus clade B. Post-transport survivorship of outplanted urchins was measured in paired open and closed cages in three different reef environments (lagoon, reef flat and reef slope) for a month. Survivorship in closed cages was highest on the reef flat $(\sim 75 \%)$, and intermediate in the lagoon and reef slope $(\sim 50 \%)$. In contrast, open cages showed similar survivorship on the reef flat and in the lagoon, but only $20 \%$ of juvenile urchins survived in open cages placed on the reef slope. Urchins grew significantly faster on diets of $G$. salicornia ( $1.58 \mathrm{~mm} /$ week $\pm 0.14 \mathrm{SE}$ ) and Kappaphycus clade $B(1.69 \pm 0.14 \mathrm{~mm} / \mathrm{wk})$ than on $E$. denticulatum $(0.97 \pm 0.14 \mathrm{~mm} / \mathrm{wk})$, with intermediate growth when fed on $A$. spicifera (1.23 $\pm 0.11 \mathrm{~mm} / \mathrm{wk})$. Interestingly, urchins display size-specific feeding preferences. In non-choice feeding trials small urchins (17.5-22.5 mm test diameter) consumed G. salicornia fastest ( $6.08 \mathrm{~g} /$ day $\pm 0.19 \mathrm{SE}$ ), with A. spicifera (4.25 $\pm 0.02 \mathrm{~g} /$ day) and Kappaphycus clade $B(3.83 \pm 0.02 \mathrm{~g} /$ day) intermediate, and $E$. denticulatum was clearly the least consumed ( $2.32 \pm 0.37 \mathrm{~g} / \mathrm{day})$. Medium-sized (29.8-43.8 mm) urchins likewise preferentially consumed G. salicornia $(12.60 \pm 0.08 \mathrm{~g} /$ day $)$, with less clear differences among the other species in which $E$. denticulatum was still consumed least ( $9.35 \pm 0.90 \mathrm{~g} /$ day). In contrast, large urchins (45.0-65.0 mm) showed no significant preferences among the different algae species at all (12.43 - $15.24 \mathrm{~g} /$ day). Overall consumption rates in non-choice trials were roughly equal to those in the choice trials, but differences among feeding rates on each species were not predictive of feeding preferences when urchins were presented all four species simultaneously. In the choice feeding trials, both small and medium urchins clearly preferred A. spicifera over all other algae (roughly twice as much consumed as any other species). Again, however, differences were less pronounced among adult urchins, with 
adults showing a significant preference for $A$. spicifera and Kappaphycus clade $B$ compared to the other two algal species. These findings indicate that outplanted urchins are surviving on the reef flats and eating a variety of alien invasive algae as intended. Although juvenile urchins show stronger feeding preferences, these animals grow quickly, and adult urchins are more generalist herbivores that consume all four alien invasive algae. 
2 Charley E. Westbrook: Hawai`i Institute of Marine Biology, University of Hawai`i at Mānoa.

3 Correspondence: Charley Westbrook, HIMB, 46-007 Lilipuna Rd, Kāne`ohe, HI 96744, USA.

4 Email: charleye@hawaii.edu

5 Rory R. Ringang: Hawai' $i$ Institute of Marine Biology, University of Hawai'i i at Mānoa.

6 Sean Michael A. Cantero: Hawai' $i$ Institute of Marine Biology, University of Hawai ‘ $i$ at

7 Mānoa.

8 HDAR \& TNC Urchin Team (group authorship): State of Hawai‘i, Division of Aquatic

9 Resources from the Division of Land and Natural Resources (David Cohen, Jono Blodgett, Brian

10 Neilson, Andrew Purvus, Frank Mancini, Tristan Walker, Brad Stubbs, Derek LeVault, Cathy

11 Gewecke, Vince Calabrese, Karen Brittain, Neil Rodriguez, Shealin Johnson) \& The Nature

12 Conservancy (Ryan Carr, Hank Lynch, Justin Dennis, Kirsten Fujitani).

13 Robert J. Toonen: Hawai'`i Institute of Marine Biology, University of Hawai ${ }^{1} i$, University of

14 Hawai'i at Mānoa. 


\section{Introduction:}

Within the last 70 years, Kāne'ohe Bay has become home to many introduced and invasive algal species, whose aggressive growth has smothered corals and overgrown many patch reefs across the bay (Coles et al. 2002; Conklin \& Smith, 2005; Smith et al 2004, Stimson et al. 2001; Russel \& Balazs, 2009; Bahr et al. 2015). Some of these alien algae species were introduced intentionally, whereas others have unknown origins (are cryptogenic), but appear to have gained a foothold in Kāne'ohe Bay thanks to a combination of reduced grazing intensity and high nutrient influx as a result of sewage discharge into the bay (Stimson et al. 2001). Among the most obvious and ecologically dominant of these invasive algal species are Kappaphycus clade B, Eucheuma denticulatum, Gracilaria salicornia, and Acanthophora spicifera. The species level taxonomy of Kappaphycus remains a subject of contention (Conklin et al. 2009; Sherwood et al. 2010). Due to the uncertain nomenclature of Kappaphycus in the literature, it was suggested we use the most contemporary denomination of the alga (despite the prospect of its name changing again, this is the best we could do at the time), henceforth it should and will be referred to as Kappaphycus clade B in this study (K. Conklin \& A. Sherwood pers. comm.).

Native species of algae which once dominated the Bay (Stimson et al. 2001; Smith et al. 2004; Conklin \& Smith 2005; Stimson et al. 2007) have become comparatively rare as the rhodophytes $K$. clade B and G. salicornia both spread rapidly across Kāne'ohe Bay after their introduction, and are now found at high abundance throughout the Bay (Hunter \& Evans 1995; Smith et al. 2002; Bahr et al. 2015). Originally these alien species were estimated to spread at a minimum rate of $250 \mathrm{~m} \mathrm{yr}^{-1}$ (Rodgers \& Cox 1999), although this is now considered to have been a gross underestimate (Coles et al. 2002; Smith et al. 2002). Since its introduction and release in 
1974, $K$. clade B has resulted in phase-shifts across the bay by replacing native algae and corals

40 with newly formed monocultures of this alien alga over large areas of reef flat and slope (Coles

41 et al. 2002; Smith et al. 2002). Likewise alien algal overgrowth is smothering live corals on

42 patch reefs, resulting in a loss of biodiversity, changes in community structure of the reef fishes,

43 and erosion of the physical structure of the reef (Smith et al. 2002). In response to the spread of

44 ecological impacts associated with these alien invasive species, the State of Hawai' $i$ Division of

45 Aquatic Resources (DAR) and The Nature Conservancy (TNC) have undertaken manual removal

46 efforts using suction-assisted divers supported by the "supersucker" barges. The "supersucker"

47 teams selectively remove invasive algae species from reefs with sorters on the surface looking

48 for any native species accidentally removed from the reef. Materials that are sucked up through

49 the pumps are sorted on the deck of the barge and any non-alien algae species are returned to the

50 reef immediately. The alien algae is bagged and given to organic farmers who use it as natural

51 fertilizer. However removal of alien algae by these teams is labor-intensive and only effective if

52 the algae do not regrow, which was happening within roughly a year in the initial supersucker

53 trials (DAR \& TNC pers. comm.). Thus, the long-term solution proposed for areas where

54 invasive algae have begun to overgrow and smother native corals has been to increase the

55 population of native herbivores such as grazing urchins (Conklin and Smith 2005; Stimson et al.

56 2007; Weis \& Butler, 2009).

57 Biocontrol agents have been the topic of much debate due to infamous cases during

58 which their introduction lead to their subsequent invasion (Howarth 1983; Simberloff \& Stiling,

59 1996). Introduced biolcontrol agents, which turned invasive, have wreaked irreversible damage

60 to many host ecosystems (Howarth 1991). Notable instances of failed biocontrol efforts in

61 Hawai'i include the introduction of the Rosy Wolf Snail (Howarth 1985, Holland et al. 2012), as 
62 well as the Indian Mongoose (Simberloff et al. 2000; Godwin et al. 2006). Indeed there are

63 precious few examples of successful biocontrol efforts with alien species (Howarth 1983;

64 Godwin et al. 2006). Many now argue that if biocontrol agents are to be used at all, they should

65 be native to the ecosystem being targeted (Howarth 1985). In addition to eliminating the

66 likelihood that alien biocontrol agents become pests in a novel environment, it has been

67 documented that native grazers suppress the establishment of exotic plants better than the

68 introduction of exotic grazers (Parker et al. 2006; Kimbro et al. 2013).

69 Following on that logic, experiments with native sea urchins have demonstrated that $T$.

70 gratilla have reduced the biomass of the invasive Kappaphycus spp. within enclosure areas on

71 the reef where alien algae were abundant (Conklin \& Smith 2005). Urchins are an important part

72 of the macro-grazing fauna on many tropical reefs, including those in Hawai'i (Chiappone et al.

73 2002; Alves et al. 2003; Mumby et al. 2006; Stimson et al. 2007; Sandin et al. 2010; Valentines

$74 \&$ Edgar, 2010). Although some urchins show dietary preferences in laboratory studies (e.g.,

75 Stimson et al. 2007; Seymour et al. 2013), others appear to be generalist herbivores that will

76 graze on just about any algae or sea grass made available (e.g., Vaïtilington et al. 2003;

77 Dworjanyn et al. 2007). Other potential biocontrol agents, such as fish (acanthurids and scarids)

78 exhibit a relatively low degree of preference for the invasive algae, are far more motile, and are

79 highly prized by local fishermen, making it difficult to rely on herbivorous fishes as a potential

80 mechanism of biocontrol (Conklin \& Smith 2005). Urchins therefore make an obvious choice

81 for a variety of algal biocontrol efforts because of their generalist feeding behavior and limited

82 vagility as adults, coupled with the high dispersal potential and the ubiquity of habitat that has

83 allowed a number of tropical urchins to successfully colonize reefs across the globe (Lessios et

84 al. 2003; Seymour et al. 2013). Likewise, T. gratilla was historically abundant in Kāne'ohe Bay 
85 (Ogden et al. 1989; Thomas 1994), but for unknown reasons has become rare since the 1990s

86 (Stimson et al. 2007; Bahr et al. 2015).

87 Studies on the ecological impacts of natural outbreaks of $T$. gratilla corroborated the

88 efficiency with which these urchins can significantly reduce the abundance of algae (Valentine \&

89 Edgar 2010). Due to their limited movement as adults and their voracious appetite for a wide

90 variety of algae and seagrasses, $T$. gratilla has been recommended as the best species for use as a

91 biological control agent in Kāne'ohe Bay (Conklin and Smith 2005; Stimson et al. 2007). Since

92 2010, DAR has been culturing juvenile T. gratilla for outplanting as herbivorous biocontrol

93 agents to prevent regrowth of algal biomass once the alien algae have been manually removed

94 from patch reefs in Kāne'ohe Bay (Gibo et al. 2012). This study set out to investigate if tank

95 bred urchins would eat the targeted alien algae species, and if so, to determine their potential

96 grazing rates. The project also examined if the urchins' growth could be sustained on diets of

97 non-native algae, and to what extent each alga facilitated growth of $T$. gratilla. Potential feeding

98 preferences between the four alien algae were also evaluated. Lastly, urchins were caged in

99 various habitats in order to elucidate post-transplant survival of tank bred juvenile urchins in the 100 bay.

101 Currently, thousands of cultured urchins are outplanted at $20-25 \mathrm{~mm}$ test diameter, but

102 comparatively few were observed in subsequent surveys of urchin density on the reef ( $\mathrm{J}$.

103 Blodgett, DAR, pers. comm.). A major motivation of this research was that it was unknown at

104 that time whether the missing urchins were dying from transplant stress, starvation, being eaten

105 by predators after outplanting, or simply moving into cryptic habitats at small sizes such that

106 they were missing in subsequent surveys. Stimson et al. (2007) conducted feeding preference

107 trials with large $T$. gratilla $(8-9 \mathrm{~cm})$ and showed that feeding preferences were generally 
108 unchanged after 5 months on monospecific diets, except urchins that were maintained on Padina

109 sanctae-crucis and showed enhanced preference in subsequent choice trials, whereas those

110 maintained on G. salicornia tended to avoid it when offered five species from which to choose at

111 the end of the trial. Further, Stimson et al. (2007) found that urchins offered a variety of algal

112 species consume more per day than when limited to a single-species diet. This study expands on

113 the previous work to elucidate patterns of the post-transport juvenile urchin survival, growth and

114 diet preferences of lab cultured T. gratilla being outplanted in Kāne'ohe Bay. Together, these

115 studies will aid both State and conservation group efforts to control alien algal overgrowth of

116 corals on reefs in Kāne'ohe Bay and across Hawai'i.

118 Materials and Methods:

119 Study Animal:

120 The short-spined collector urchin Tripneustes gratilla received its common name from

121 the habit of gathering fragments of coral rubble, rocks, or algae from the benthic environment as

122 camouflage while it forages. Its body is predominantly black but often possesses a pentaradial

123 bluish or reddish hue when its tube feet are retracted close to its body. Its spines are typically

124 black, white or cream. This echinoid is relatively common in shallow waters $(0-15 \mathrm{~m})$ across the

125 Hawaiian archipelago (Kay 1994; Hoover, 2002). Natural densities of T. gratilla range from 2.9-

$1264.4 \mathrm{~m}^{-2}$, placing it in the top three most abundant urchins in Hawai' $\mathrm{i}$ (Ogden et al. 1989).

127 Although T. gratilla have shown significant dietary preferences for Kappaphycus spp. in

128 controlled laboratory studies (Stimson et al. 2007), in the wild these urchins are a generalist

129 herbivore that will graze on virtually any algae or sea grass available (Vaïtilington et al. 2003;

130 Dworjanyn et al. 2007; Stimson et al. 2007). The generalist diet and habitat requirements of $T$. 
131 gratilla coupled with high dispersive potential have resulted in an extremely wide, pantropical

132 distribution (Lessios et al. 2003). It should be noted that $T$. gratilla was formerly a native

133 resident of Kāne'ohe Bay. Tripneustes gratilla was once thought to be one of the most abundant

134 urchin species within Kāne`ohe Bay (Edmonson, 1946; Alender, 1964; Banner \& Bailey 1970;

135 Kay, 1994). Conversely, $T$. gratilla is now relatively rare and does not contribute significantly to

136 herbivory on reefs within the bay (Conklin and Smith, 2005; Stimson and Conklin, 2008).

137 However, historical outbreaks of the native alga Dictyospaeria were thought to be controlled by

$138 T$. gratilla because growth accumulated mostly in calm waters of the bay where the urchin was

139 rare (Banner \& Bailey 1970). Hence, there is considerable interest from both State and local

140 conservation groups to replenish the natural population of $T$. gratilla in the bay and enhance

141 natural herbivory to control these invasive alien algal species.

142 Tripneustes gratilla were provided by the DAR urchin hatchery as juveniles. We

143 arbitrarily placed urchins in three non-overlapping size classes: small (17.5-22.5mm maximum

144 test diameter), medium $(29.8-43.8 \mathrm{~mm})$, and large $(45.1-65.1 \mathrm{~mm})$ that were then used for each of

145 the experimental trials outlined below. Prior to the experiments, medium and large urchin size

146 classes were raised on diets of all four alien algae. Small urchins were not fed before trials, but

147 instead were placed directly into experiments within a few days of arriving from the hatchery.

148 Therefore, urchins were starved 3-5 days prior to each experiment.

149 Algae:

We chose the four most common species of alien invasive algae found on the

151 patch reefs of Kāne'ohe Bay: Acanthophora spicifera, Gracilaria salicornia, Eucheuma

152 denticulatum, and Kappaphycus clade B. Kappaphycus clade B (formerly identified as

153 Kappaphycus alvarezii, K. striatum, or Eucheuma striatum) and Eucheuma denticulatum were 
154 intentionally introduced from the Philippines to Kāne'ohe Bay September 1974 by researchers

155 from the University of Hawai'i for scientific research (Doty 1971; Doty 1977); fragments

156 apparently drifted away from test sites on the north reef of Moku O Lo'e (Coconut Island) and

157 were also collected and transplanted around the bay by local residents for personal cultivation

158 (Russel, 1983; Batibasaga et al. 2003; Weis \& Butler, 2009). Despite having observed

159 vegetative propagules being released, researchers reported that such propagules were incapable

160 of dispersing over deep water or finding suitable hollows on which to settle (Doty, 1977). This

161 oversight led to the documented proliferation of new eucheumatoid colonies upon the

162 introduction of the algae to test sites around Coconut Island (Doty, 1977). Likewise, the

163 intentional introduction of Gracilaria salicornia by the same researchers to Kāne'ohe Bay

164 occurred September of 1978, specifically for experimental aquaculture aimed at the development

165 of commercial agar production (reviewed by Rodgers \& Cox, 1999; Smith et al. 2004). The idea

166 of a commercial agar industry in Hawai' $i$ has long since been abandoned, but the introduced $G$.

167 salicornia has established and spread along the shores of Waikīkī and reefs in Kāne'ohe Bay.

168 In contrast to these intentional introductions, a fragment of Acanthophora spicifera was

169 first documented in Pearl Harbor in the fall of 1952, and was believed to have been transported

170 on the heavily fouled hull of the barge "Yon 146" which was towed to O'ahu from Guam in 1950

171 (Doty, 1961). By February 1956, A. spicifera had been documented in Kāne'ohe Bay, making it

172 the first documented accidental introduction to the Bay (Kohn, 1961; Coles et al. 2002). These

173 invasive macrophytes became not only some of the most dominant benthic organisms, but they

174 have also resulted in the most detrimental impacts to marine communities in the bay (Coles et al.

175 2002). 
The four algae species had widespread distributions in the bay and were readily available

177 for collection. Acantohophora spicifera and G. salicornia were easily collected nearly anywhere

178 around Coconut Island and around the southern portion of Kāne'ohe Bay. The eucheumoids

179 were consistently collected from patch reefs in the central portion of the Bay. We did not

180 included native algae in this study because their abundance is so reduced in the Bay (Stimson et

181 al. 2001; Conklin \& Smith 2005; Stimson et al. 2007) that we could not collect enough for this

182 experiment without impacting the remaining population.

183

184 Growth on Single-species Diet

185 Growth rates of $T$. gratilla were measured while on single-species diets of each $A$.

186 spicifera, G. salicornia, E. denticulatum and K. alverezii. For each of the four algal species, three

187 T. gratilla were housed in each of three $15 \mathrm{~L}$ replicate aerated flow-through tanks $(\sim 1-2 \mathrm{~L} / \mathrm{min})$.

188 In order to monitor individual growth rates of urchins without marking the animals, each tank

189 held a single urchin of each size class: small, medium, and large. For each treatment, algae were

190 provided ad libitum to reduce any resource competition, and all aquariums were cleaned twice a

191 week during which freshly collected algae were provided to each tank. Urchin test diameter was

192 measured using Vernier calipers (VWR) to the nearest tenth of a millimeter each week for a

193 month. An analysis of covariance (ANCOVA) was employed to analyze growth, with initial

194 urchin test size used as the covariate. Tukey's HSD post-hoc comparison was then performed to

195 determine significance of pairwise differences in average growth rates of urchins on each algae

$196 \operatorname{diet}$ (Fig. 1).

197

198

No-Choice Feeding Trials: 

species of alga and measured differences in mean consumption among the treatments with different algal species. For each algal species, two urchins of the same size class were added to each of six replicate tanks (15L tanks with 1-2L/min flow rate, as above). Algae were blotted on paper towels to remove excess water and weighed before being placed in each tank. Urchins were allowed to graze for $\sim 5$ days and the amount of remaining algae was weighed as before to calculate the amount of each species consumed per urchin per day. In a few cases we stopped the experiment after the $4^{\text {th }}$ day because we did not want the urchins to consume more than half of the algae offered in any trial. Consumption rates (grams of algae per day) were then compared by analysis of variance (ANOVA). Tukey's HSD post-hoc comparison was used to identify significant differences between each of the algae (Fig. 2). The assumptions of

210 Normality and homogeneity of variance of the data were tested using the Shapiro-Wilks test and

211 the Levene's test, respectively. The null hypothesis for the Shapiro-Wilks test was that the data

212 were Normally distributed; therefore, p-values less than 0.05 suggested that the data were not

213 Normally distributed. For the small size class in the no-choice feeding trials the data were

214 Normally distributed (Shapiro-Wilk, $\mathrm{W}=0.96, \mathrm{p}=0.82$ ). The data from the medium cohort from

215 the no-choice trial was also normally distributed (Shapiro-Wilk, $\mathrm{W}=0.90, \mathrm{p}=0.28$ ). However,

216 the data from the large urchins of the no-choice feeding trial were only marginally non-normal

217 (Shapiro-Wilk, $\mathrm{W}=0.80, \mathrm{p}=0.042$ ). To test the homogeneity of variance among our feeding

218 trial data, the Levene's test was employed. The null hypothesis for the Levene's test was that the

219 variances are homogenous. For the urchins in the no-choice feeding trials, the data passed the

220 homogeneity test (Levene's test, $\mathrm{F}(3,44)=0.56, \mathrm{p}=0.64)$. 


\section{Choice Feeding Trials:}

223

224

225

226

227

228

229

230

231

232

233

234

235

236

237

238

240

241

242

243

The choice feeding experiment provided all four species of algae, in equivalent amounts, simultaneously to urchins. As with no-choice experiments above, each algal species was blotted and weighed before being introduced to the experimental tanks. For this assay, larger tanks ( $80 \mathrm{~L}, \sim 4 \mathrm{~L} / \mathrm{min}$ flow-through) were used to allow room to separate algae into the four quadrants of the experimental tank. Four urchins were then introduced to the middle of the tank and allowed to graze at will for $\sim 7$ days. Again, if any species of alga became low relative to the others (less than half the initial amount), we stopped the experiment a day early to avoid biasing results. At the end of each experiment, algae were removed, blotted and weighed as previously to calculate the amount of algae consumed per urchin per day for each species.

For each choice and no-choice feeding trials, small urchins were provided with $\sim 100 \mathrm{~g}$ of algae initially, whereas medium and large urchins were offered a starting biomass of $\sim 150 \mathrm{~g}$ of algae. To account for any growth or decline of the algae not attributed to urchin grazing during the experiment, both choice and no-choice experiment tanks had a divider such that one half of the tank housed experimental algae and urchins whereas the other side housed only equivalent amounts of algae to serve as a no urchin control. The consumption rates of algae were then calculated as:

Consumption $=\left(A_{i}\left(A C_{f} / A C_{i}\right)-A_{f}\right)$

Where $A_{i}$ and $A_{f}$ were the initial and final blotted masses of algae subject to grazing by urchins; while $A C_{i}$ and $A C_{f}$ were the initial and final masses of the algae in the no-urchin control tanks. This equation was used to account for growth of algae over the course of the experiment, but can also account for any unexpected decline in algal biomass unrelated to the grazing trial (Dworjanyn et al. 2007; Seymour et al. 2013). Because all species of algae were provided 
245 simultaneously during choice feeding trials, the consumption of one species was affected by the

246 consumption of the others, therefore the assumption of independence required to perform an

247 ANOVA was violated. Consequently, choice feeding preference assays were analyzed using a

248 non-parametric Friedman's rank test, and both parametric and non-parametric analyses are

249 congruent. Relative consumption rates of each algal species were reported (Fig. 3) and ranked.

250 Nevertheless, due to the lack of post-hoc pairwise comparison for Friedman's rank test, a

251 Tukey's HSD post-hoc comparison was used to identify significant differences between each of

252 the algae. Again, to test the data's distribution for Normality and homogeneity of variance the

253 Shapiro-Wilk and Levene's test were used. The data from the small urchins of the choice

254 feeding trials failed the normality test (Shapiro-Wilk, $\mathrm{W}=0.86, \mathrm{p}=0.0036$ ). However, the data

255 for the medium and large sized urchins of the choice feeding trials both passed the normality test

256 (Shapiro-Wilk, $\mathrm{W}=0.97, \mathrm{p}=0.27$, and $\mathrm{W}=0.96, \mathrm{p}=0.17$, respectively). For the small urchins

257 of the choice feeding trial, the data passed the homogeneity test (Levene's test, $F(3,20)=2.13$, $p$

$258=0.13)$. The data from the medium urchins in the choice feeding trial fail to reject the null

259 hypothesis (Levene's test, $\mathrm{F}(3,36)=0.32, \mathrm{p}=0.81$ ). The data from the cohort of large urchins in

260 the choice feeding trials also passed the test for equality of variances (Levene's test, $\mathrm{F}(3,40)=$

$2611.98, \mathrm{p}=0.13)$.

262

263 Field Caging Experiment:

264 Cages measuring roughly $50 \times 50 \times 75 \mathrm{~cm}$ were constructed from $1 \mathrm{~cm}^{2}$ galvanized chicken

265 wire mesh. We constructed both open and closed cages. For closed cages, the mesh extended

266 across all sides including the tops to prevent urchins from being able to crawl out and prevent

267 access by fishes on the reef. In contrast, the sides of the open cages end with back-folded edges 
268 and no top to minimize escape of the juvenile urchins from the cage, but still allow open access

269 of predatory fishes. Initial trials with urchins caged in seawater tables indicated that this back-

270 folded edge design (approximating an upside down U) was the most effective for open cages, but

271 urchins still escaped the cages at the rate of 1-2 animals per week. Urchins ranged from 18-

$27222 \mathrm{~mm}$ at the start of the experiment. Cages were filled with G. salicornia to provide the juvenile

273 urchins with food and a place to hide, because our initial aquarium trials revealed that urchins

274 were far more likely to escape the open cages in the absence of hiding spots and food in the cage.

275 In the absence of any cover or food, open cages were frequently empty within 24 hours in our 276 water table trials (data not shown).

277 Cages were placed at 6 sites across three habitats, with four cages, three open and one 278 closed control, at each site. 251 urchins were used during these caging experiments. Three 279 habitats surrounding Coconut Island (map in supplementary materials) were selected to mimic 280 the conditions on the reef to which urchins are being currently outplanted: a protected lagoon, a 281 shallow back-reef and a fore-reef slope each at 1-3m depth. The protected lagoon had low coral 282 cover, high alien algal cover and minimal water flow, whereas both the back-reef and fore-reef 283 sites had high coral cover, relatively low alien algal cover and relatively high water flow. Each 284 cage was checked three times a week for 30 days to count surviving urchins as well as replenish 285 consumed algae. All studies reported here were conducted under the State of Hawai' $i$, 286 Department of Land and Natural Resources, Division of Aquatic Resources Special Activity 287 Permits sap\#2012-63 and SAP\#2013-47. Survivorship between treatments was compared using 288 the Kaplan-Meier product-limit method for fitting survivorship curves and comparison by Log289 rank (Forsman et al. 2006), and Wilcoxon non-parametric tests. These statistical tests were done 290 using JMP Pro 11. 
292 Results:

293 Growth on Single-species Diet:

294 Growth rates of $T$. gratilla, measured as maximum test diameter (mm), were significantly

295 affected by fixed algal diets (ANCOVA, initial urchin size as covariate, $\mathrm{F}_{(5,84)}=10.80, \mathrm{p}<0.001$,

296 Fig. 1). Urchins that fed exclusively on diets of either G. salicornia or K. clade B grew at

297 significantly $(\mathrm{p}=0.001$ and $\mathrm{p}=0.009$, respectively, Tukey HSD) higher rates $(1.58 \pm 0.14$ and

$2981.69 \pm 0.14 \mathrm{~mm} /$ week TD (Test Diameter), respectively) than those urchins that fed on a diet of

299 E. denticulatum. Urchins that fed on a diet of E. denticulatum had the lowest growth rates $(0.97$

$300 \pm 0.14 \mathrm{~mm} /$ week TD) out of the four assays, though not significantly lower to urchins on a diet of

301 A. spicifera $(1.23 \pm 0.11 \mathrm{~mm} /$ week TD $)$.

302

303 No-choice Feeding Trials:

304 When presented with no choice, urchins consumed different species of algae at different

305 rates, but the effect varied by urchin size (Fig. 2). On average, large urchins ate G. salicornia at

306 the highest rate of all algal species offered $\left(15.24 \pm 0.001\right.$ g.day $\left.^{-1}\right)$, and $K$. clade B at the lowest

307 rate $\left(12.43 \pm 1.51\right.$ g.day $\left.^{-1}\right)$ although these trends were not significant $\left(A N O V A, F_{(3,12)}=1.94, p\right.$

$308=1.78$, Fig 2C). Medium sized urchins showed similar trends, but with significant differences in

309 the amounts of algae they consumed on a daily basis (ANOVA, $\mathrm{F}_{(3,12)}=8.49, \mathrm{p}<0.05$, Fig. 2B).

310 For the medium size class, Gracilaria salicornia was eaten at a significantly higher rate $(12.60 \pm$

3110.08 g.day $\left.^{-1}\right)$ than either $A$. spicifera $\left(10.33 \pm 0.36\right.$ g.day $\left.^{-1}\right)$ or $E$. denticulatum $\left(9.35 \pm 0.90\right.$ g.day $^{-}$

$\left.312^{1}\right)(p=0.034$ and $p=0.003$, respectively, Tukey HSD $) ; K$. clade B was also eaten at a higher rate

$313\left(11.87 \pm 0.27\right.$ g.day $\left.^{-1}\right)$ than E.denticulatum $(\mathrm{p}=0.018$, Tukey HSD), but not $A$. spicifera $(\mathrm{p}>$ 
3140.05 , Tukey HSD). Among the small collector urchins, feeding rate patterns were comperable to

315 those of the medium urchins, but with more significant disparities among algal species,

316 (ANOVA, $\mathrm{F}_{(3,12)}=51.30, \mathrm{p}<0.001$, Fig. 2A). Small urchins offered only G. salicornia had a

317 significantly higher mean consumption rate $\left(6.08 \pm 0.19\right.$ g.day $\left.^{-1}\right)$ than any other algal assay in

318 the non-choice feeding trial $(\mathrm{p}<0.05$ for each pairwise comparison, Tukey HSD). Small urchins

319 likewise consumed Eucheuma denticulatum at the lowest rate $\left(2.32 \pm 0.39\right.$ g.day $\left.^{-1}\right)$, which was

320 significantly lower than both $A$. spicifera and $K$. clade B ( $<<0.05$, Tukey HSD).

322 Choice Feeding Trials:

323 Feeding trials in which urchins were offered multiple species of algae simultaneously

324 revealed different patterns than those observed in the non-choice feeding assays. Small urchins

325 significantly preferred to feed on A. spicifera than any of the other three available algae species

326 (Friedman's rank test, $\mathrm{p}<0.05 ; \mathrm{p} \leq 0.01$, Tukey HSD, Fig. 3A). Small urchins did not display

327 any patterns of preference among G. salicornia, E denticulatum or $K$. clade B ( $\mathrm{p}>0.05$, Tukey

328 HSD). Likewise medium urchins showed a significant preference (Friedman's rank tests, $\mathrm{p}<$

329 0.001, Fig. 3B) for A. spicifera over G. salicornia and $K$. clade B ( $\mathrm{p}<0.05$ and $\mathrm{p}<0.001$,

330 respectively, Tukey HSD), as it was consumed at the highest rate $\left(3.69 \pm 0.21\right.$ g.day $\left.^{-1}\right)$, whereas

331 G. salicornia and E. denticulatum were consumed at intermediate rates $(0.95 \pm 0.1$ and $1.19 \pm$

3320.13 g.day $^{-1}$, respectively). In contrast, medium urchins consumed $K$. clade B at the lowest rate

$333\left(0.51 \pm 0.10\right.$ g.day $\left.^{-1}\right)$. Unlike the small and medium urchins, which avoided $K$. clade B in the

334 choice trials, large urchins exhibited significant preferences for both $A$. spicifera and $K$. clade B

$335\left(4.30 \pm 0.09\right.$ g.day $^{-1}$ and $4.31 \pm 0.14$ g.day $^{-1}$, respectively) in the choice feeding trials

336 (Freidman's rank test, $\mathrm{P}<0.001$, Fig. 3C). Large urchins significantly preferred A. spicifera to 
337 both G. salicornia and E. denticulatum ( $\mathrm{p}<0.0001$ and $\mathrm{p}<0.001$, respectively, Tukey HSD).

338 Kappaphycus clade B was also significantly preferred to G. salicornia and E. denticulatum ( $\mathrm{p}<$

3390.01 and $\mathrm{p}<0.05$, respectively, Tukey HSD). Whereas G. salicornia and E. denticulatum were

340 consumed at intermediate rates by small and medium urchins, these species tend to be avoided

341 by the large urchins $\left(3.11 \pm 0.20\right.$ g.day $^{-1}$ and $3.20 \pm 0.20$ g.day $^{-1}$, respectively) when given a

342 choice of algae on which to feed (Fig 3).

343

344 Caging Experiment:

345 Considerable differences in urchin survivorship among the three habitats that they were

346 caged in were found to be significant (Table 1). On the reef flat, $84.4 \%$ of urchins deployed in

347 closed cages remained and $75 \%$ of urchins remained in the open cages after 29 days (Fig. 4A).

348 Urchins caged in the lagoon had a substantially higher rate of loss than those on the reef flat,

349 with only $56.3 \%$ of urchins remaining after 29 days, regardless of cage type (Fig. 4B). After 29

350 days, $55.2 \%$ of urchins remained in closed cages, but only $20 \%$ survived in the open cages,

351 giving urchins deployed on the reef slope the highest rate of loss (Fig. 4C).

352

353 Discussion:

354

Increasing the abundance of native grazers would not only control and remove current

355 alien invasive algae species, but it would also serve to increase the degree of biotic resistance to

356 novel invasive species (Kimbro et al. 2013). Consistent with previous studies (e.g., Lawrence \&

357 Agatsuma 2001; Seymour et al. 2013), Tripneustes gratilla is a generalist herbivore that

358 managed to grow on every species of algae tested, and fed on all algal species offered to them

359 without exception. However, T. gratilla did not interact with every species of algae 
360 indiscriminately. The urchins experienced variable growth depending on the diet they fed on.

361 They did not feed on all rhodophytes at the same rate, and even exhibited preferences between

362 the available species when presented with a choice of all four alien algae species. All of the

363 algal diets supported growth, but the algae species that supported the highest growth rates were

364 G. salicornia and K. clade B, whilst urchins that fed solely on E. denticulatum had the lowest

365 growth rates, and A. spicifera sustained intermediate growth (Fig. 1). The reason for differential

366 growth was not investigated, but could possibly be attributed to variation in nutritional content,

367 consumption rate, digestibility or assimilation efficiency (Sterner \& Hessen 1994). For example,

368 growth rates may be higher on G. salicornia than A. spicifera because Gracilaria contains more

369 protein than does Acanthophora (McDermid et al. 2007). Likewise, the low growth rate of

370 urchins on a diet of $E$. denticulatum could result from the comparatively high dietary fiber of this

371 alga, a compound that resists digestion and lowers assimilation efficiency (McDermid et al.

372 2005).

373 As with consumption rates, feeding preferences were also observed to vary among size

374 classes (Fig. 3). The differences in feeding preference and consumption rates could translate into

375 urchins of different size classes having differential impacts on alien algae, and argue that

376 biocontrol efficiency could be increased by outplanting urchins of the correct size class for the

377 dominant algal species to be controlled. For example, urchins of all size classes consumed $A$.

378 spicifera preferentially in choice experiments (Fig. 3). Acanthophora spicifera is known to be

379 consumed by other native grazers (Wylie \& Paul, 1988; Russell \& Balazs 1994), but the effects

380 of alien algal ingestion on the diets of native herbivores remains unknown (Smith et al. 2004).

381 Our results show a greater disparity of preference among smaller than larger urchins (Fig. 3),

382 suggesting that the role of alien algae in the diets of native grazers may vary ontogenetically. 
383 Nevertheless, small urchins showed a significant preference for A. spicifera relative to all other

384 species, whereas larger urchins showed a higher affinity for both A. spicifera and K. clade B.

385 Despite being a preferred species in all choice feeding trials, urchins did not seem to grow at a

386 significantly different rate $(1.23 \pm 0.11 \mathrm{~mm} /$ week test diameter $)$ when fed only A. spicifera

387 relative to any other algal diet (Fig. 1). In fact, growth rates appeared maximal on a diet of $G$.

388 salicornia which was less preferred in all choice feeding trials (Fig. 3).

389 Our results contrast those presented by Stimson et al. (2007), which focused solely on

390 large adult urchins ( $7-8 \mathrm{~cm}$ test diameter), and showed a significant preference of urchins for

391 Kappaphycus spp. but without including Eucheuma denticulatum in the feeding trials. Here we

392 find that consumption rates of each algal species vary by size class, and we see no significant

393 differences among consumption rates of algal species for urchins in our largest size class (Fig.

394 2). Given the strong differences seen in diet preference among urchins of different size classes,

395 the discrepancy between our results and those of Stimson et al. (2007), could result from a

396 continued change in diet preference and their use of significantly larger urchins than used in our

397 feeding experiments. Among medium urchins, however, significantly more G. salicornia and K.

398 clade B were consumed, and the smallest urchins consumed significantly more G. salicornia

399 than the other three species (Fig. 2). Although the general trend is similar among urchin size

400 classes, the biggest differences among the consumption rates were seen in the smallest urchins,

401 which consume slightly more than twice as much G. salicornia as E. denticulatum (Fig. 2A).

402 However, as urchin test diameter increased, there was a reduction in the difference between

403 feeding assays, until all four species were consumed at statistically indistinguishable rates among

404 adult urchins in the no-choice trials; larger urchins eat more algae, and grazing rates become

405 more homogeneous among the four species of red algae (Fig. 2). Algal palatability can be 
406 reduced by increased algal toughness in a range of herbivorous species (e.g., Peters et al. 2002).

407 For some species of echinoderms, it has been documented that larger sizes (body diameter) are

408 associated with greater jaw strength (Ellers \& Telford, 1990). Thus, it may be that larger urchins

409 are better able to masticate a wider variety of algae, including species with larger and tougher

410 thalli, such as E. denticulatum and $K$. clade B.

411 It is noteworthy that despite the widespread distribution of $T$. gratilla, caged juvenile

412 collector urchins did not fare equally well in every environment. The caging experiment

413 highlighted significant differences in survivorship among potential outplanting locations (Table

414 1). Urchins placed in high algal cover, comparatively low-flow lagoonal habitats fared poorly,

415 with only $\sim 50 \%$ survivorship (Fig. 4B). Survivorship was equal for animals in both open and

416 closed cages in the lagoon, and the removal of empty tests (clear evidence of mortality)

417 accounted for all but a couple animals by the end of the month deployment. Thus, we are

418 confident that the decline in urchin number in the lagoon was a result of low survival as opposed

419 to predation or escape. Urchins caged on the reef flat consistently had the highest overall

420 survivorship rates, with nearly $80 \%$ of urchins remaining at the end of the experiment. In these

421 sites, we found only a single urchin test in any cage, and we had a few urchins somehow escape

422 the closed cages in our initial water table trials, so we cannot be sure of whether the missing

423 urchins died or escaped, but the high overall survival in both open and closed cages provides

424 evidence that placement of urchins in these habitats is likely to increase the population of

425 herbivorous urchins over time. In contrast, juvenile urchins placed on the reef slope suffered

426 mortality rates as high as $80 \%$ in open cages (Fig. 4C). Even in closed cages, survival over the

427 course of the experiment was only slightly above $50 \%$, and again we recovered only 25 total

428 tests in the cages over the course of the experiment. This seems likely to be a result of predation 
429 by reef fishes because we see a much more dramatic decline on the deeper water reef slope than

430 in the shallows of the reef flats (Fig. 4). The decline of urchins in the closed cages on the reef

431 slope below what is seen in open cages on the reef flat is somewhat puzzling. However, we

432 noted during the experiment that the saddleback wrasse, Thalassoma duperrey, was particularly

433 abundant around the urchin cages along the reef slope. Wrasses have been documented

434 harassing juvenile T. gratilla urchins (Dafni \& Tobo, 1987), and in a couple of cases, fish were

435 even found to have somehow squeezed themselves inside one of the closed cages along the reef

436 slope and were subsequently trapped in the cage on the next day. Although the mesh size was

437 intended to exclude predatory fish, it is possible that wrasses small enough to fit through $1 \mathrm{~cm}^{2}$

438 mesh may have been responsible for the decline of urchins in closed cages along the reef slope,

439 and the loss of $80 \%$ of animals from open cages within a month suggests that outplanting urchins

440 into deeper waters of the bay is simply generating a feeding station.

441 Conclusion:

442 The estimated overall productivity of these alien invasive eucheumatoids in Kāne 'ohe

443 Bay is 20.8 tonnes dry wt $/ \mathrm{ha} / \mathrm{yr}$, which translates to $5.7 \mathrm{~g} \mathrm{dry} \mathrm{wt} / \mathrm{m}^{2} /$ day (Glenn \& Doty, 1990).

444 Given this approximation of productivity and the data compiled on consumption rates, a rough

445 estimate of the ideal urchin density can be derived. Here we find that a large urchin $(45-65 \mathrm{~mm}$

446 TD) could graze $\sim 7.5 \mathrm{~g}$ of alien algae per day when presented with a mixed diet. This back-of-

447 the-envelope calculation suggests that the grazing rate of one adult urchin $/ \mathrm{m}^{2}$ may be just about

448 equal to the predicted growth rates of these algae. Additionally, our caging experiments indicate

449 that mortality rates for juvenile urchins in open cages on the reef flat are on the order of $25 \%$.

450 Thus, a target density of two urchins $/ \mathrm{m}^{2}$ is recommended to overcome growth and reduce the

451 biomass of alien algae if urchin grazing is to be effective for biocontrol. Given the high 
452 mortality rates for juvenile urchins on the deeper reef slope and the protected lagoon habitats, it

453 is not advisable to invest the effort to culture and outplant juvenile urchins in either environment.

454 Although there is variability in growth rates, juvenile urchins tend to grow quickly and the

455 largest size class of urchins we tested showed no significant preferences among any of the target

456 alien invasive algal species. Given that current efforts by conservation groups aim to manually

457 remove alien algae and then outplant native urchins to the reef flats, where survivorship was

458 high, this study increases confidence that intentional outplanting of juvenile urchins is likely to

459 be an effective means of biocontrol for these invasive alien algae.

\section{References:}

462

463

464

465

466

467

468

469

470

471

472

473

Alender C. B. 1964. The venom from the heads of the globiferous pedicellariae of the sea urchin Tripneustes gratilla (Linnaeus). Ph.D. dissertation. University of Hawai'i at Mānoa, Honolulu, HI, USA. 126 pp.

Alves F.M.A., Chícharo L.M., Serrão E., Abreu A.D. 2003. Grazing by Diadema antillarum (Philippi) upon algal communities of rocky substrates. Scientia Marina. 67: 307-311.

Ask E.I., Batibasaga A., Zertuche-Gonzalez J.A., De San M. 2003. Three decades of Kappaphycus alvarezii (Rhodophyta) introduction to non-endemic locations. Pp. 49-57 In: Chapman A.R.O., Anderson R.J., Vreeland V.J., Davison I.R. (eds). Proceedings of the $17^{\text {th }}$ international seaweed symposium. Oxford University Press, Oxford.

Bahr K. D., Jokiel P. L., Toonen R. J. 2015. The unnatural history of Kāne 'ohe Bay: coral reef resilience in the face of centuries of anthropogenic impacts. PeerJ 3:e950 https://dx.doi.org/10.7717/peerj.950 
474 Banner A.H. \& Bailey J.H. 1970. The effects of urban pollution upon a coral reef system: a 475 preliminary report. HIMB Technical Bulletin \#25, University of Hawai'I at Mānoa. 66pp. 476 Batibasaga E.I., Zertuche-González J.A., de San M. 2003. Three decades of Kappaphycus alvarezii (Rhodophyta) introduction to non-endemic locations. Proceedings of the International Seaweed Symposium. 17: 49-58.

Chiappone M., Swanson D.W., Miller S.L., Smith S.G. 2002. Large-scale surveys on the Florida reef tract indicate poor recovery of the long-spined sea urchin Diadema antillarum. Coral Reefs. 21: 155-159.

Coles S.L., DeFelice R.C., Eldredge L.G. 2002. Nonindigenous Marine Species in Kāne`ohe Bay, O’ahu, Hawai'i. Bishop Museum Press. 24: 1-359.

Conklin K. Y., Kurihara A., Sherwood A. R. 2009. A molecular method for identification of the morphologically plastic invasive algal genera Eucheuma and Kappaphycus (Rhodophyta, Gigartinales) in Hawaii. Journal of applied phycology 21(6): 691-699.

487 Conklin E. J., Smith J. E. 2005. Abundance and spread of the invasive red algae, Kappaphycus spp., in Kāne'ohe Bay, Hawai'i and an experimental assessment of management options. Biological Invasions 7: 1029-1039.

Dafni J., Tobo R. 1987. Population structure patterns of a common red sea echinoid Tripneustesgratilla-elatensis. Israel Journal of Zoology. 34: 3-4. 191-204.

Doty M.S. 1961. Acanthophora, a Possible Invader of the Marine Flora of Hawaii. Pacific Science. 15: 547-552.

Doty M.S. 1977. Eucheuma-current marine agronomy. The marine plant biomass of the Pacific Northwest Coast. Krauss R.W. ed, Oregon State University Press. Corvallis, OR: 203- 
497 Dworjanyn S. A., Pirozzi I., Wenshan L. 2007. The effect of the addition of algae feeding 498 stimulants to artificial diets for the sea urchin Tripneustes gratilla. Aquaculture 273: 624499633.

500 Edmonson C. H. 1946. Reef and shore fauna of Hawaii. Bernice P. Bishop Museum Special $501 \quad$ Publication. 22: 381.

502 Forsman Z. H., Rinkevich B., Hunter C. L. 2006. Investigating fragment size for culturing reef503 building corals (Porites lobata and P. compressa) in ex situ nurseries. Aquaculture 261: $504 \quad 89-97$.

505 Gibo C., Letsom T., Westbrook C. 2012. Effects of temperature, salinity, pH, reef size, and 506 Tripneustes gratilla on the distribution of Montipora dilatata in Kāne'ohe Bay. Final 507 class report to NOAA species of Concern, Honolulu. http://www.fpir.noaa.gov/Library/PRD/SOC/M.\%20dilatata\%20SOC\%20Final\%20Repor

510 Glenn E.P., Doty M.S. 1990. Growth of the seaweeds Kappaphycus alvarezii, K. striatum and Eucheuma denticulatum as affected by the environment in Hawai' i. Aquaculture. 84: 245-

513 Godwin S., Rodgers K. S., Jokiel P. L. 2006. Reducing Potential Impacts of Invasive Marine Species in the Northwestern Hawaiian Islands Marine National Monument. Report to:

516 Holland B.S., Taylor C., Sugiura S. 2012. Tracking behavior in the snail Euglandina rosea: First 517 evidence of preference for endemic vs. biocontrol target pest species in Hawaii. American 518 Malacological Bulletin 30 (1): 153-157. 
519 Hoover J. P. (2002) “Hawai'i's Sea Creatures: A Guide to Hawai'i's Marine Invertebrates"

$520 \quad$ Mutual: 319.

521 Howarth F. G. 1983. Classical Biocontrol: Panacea or Pandora's Box. Proceedings, Hawaiian 522 Entomological Society 24: 239-244.

523 Howarth F. G. 1985. Impact of alien land arthropods and mollusks on native plants and animals 524 in Hawai'i. Hawaii's terrestrial ecosystems: preservation and management. Stone C.P. 525 and Scott J.M. ed, University of Hawaii's Cooperative National Park Resources Study Unit. . Honolulu, HI: 149-178.

527 Howarth F. G. 1991. Environmental impacts of classical biological control. Annual Review of 528 Entomology 36: 485-509.

529 Hunter C. L., Evans C. W. 1995. Coral reefs in Kaneohe Bay, Hawaii: two centuries of western 530 influence and two decades of data. Bulletin of Marine Science 57(2): 501-515.

531 Kay E. A. 1994. Marine ecosystems in the Hawaiian Islands. A Natural History of the Hawaiian 532 Islands: Selected Reading II, EA Kay (ed). University of Hawai 'i Press: USA, 187-195.

533 Kimbro D. L., Cheng B. S., Grosholz E. D. 2013. Biotic resistance in marine environments. 534 Ecology Letters 16: 821-833.

535 Kohn A.J. 1961. Studies on Spawning Behavior, Egg Masses, and Larval Development in the 536 Gastropod Genus Conus, Part I Observations on Nine Species in Hawai'i. Pacific 537 Science. 15: 163-179.

538 Lawrence J.M., Agatsuma Y. 2001. The Ecology of Tripneustes gratilla. In: Lawrence J.M. (ed) $539 \quad$ Edible Sea Urchins: biology and ecology. Elsevier, Amsterdam. p 514. 
540 Lessios H. A., Kane J., Robertson D. R. 2003. Phylogeography of the pantropical sea urchin

541 Tripneustes: contrasting patterns of population structure between oceans. Evolution 57:

$542 \quad 2026-2036$.

543 McDermid K.J., Stuercke B., Haleakala O.J. 2005. Total dietary fiber content in Hawaiian $544 \quad$ marine algae. Botanica Marina. 48: 437-440.

545 McDermid K.J., Stuercke B., Balazs G.H. 2007. Nutritional composition of marine plants in the 546 diet of the green sea turtle (Chelonian mydas) in the Hawaiian Islands. Bulletin of Marine $547 \quad$ Science. 81: 55-71.

548 Mumby P.J., Hedley J.D., Zychaluk K., Harborne A.R., Blackwell P.G. Revisiting the 549 catastrophic die-off of the urchin Diadema antillarum on Caribbean coral Reefs: Fresh insights on resilience from a simulation model. Ecological Modeling. 196: 131-148.

Ogden N. B., Ogden J. C., Abbott I. A. 1989. Distribution, abundance and food of sea urchins on a leeward Hawaiian reef. Bulletin of Marine Science 45(2): 539-549.

Parker J. D., Burkepile D. E., Hay M. E. 2006. Opposing effects of native and exotic herbivores on plant invasions. Science 301: 1459-1561.

Peters K.J., Amsler C.D., Amsler M.O., McClintock J.B., Iken K.B., Baker W.J. 2002. The Effects of Thallus Toughness and Nutritive Quality on Palatability of Antarctic Macroalgae. Journal of Phycology. 38: 29-30.

Rodgers S.K., Cox E.F. 1999. Rate of Spread of Introduced Rhodophytes Kappaphycus alvarezii, Kapphaphycus striatum, and Gracilaria salicornia and Their Current Distribution in Kāne'ohe Bay, O'ahu, Hawai' 'i. Pacific Science. 53: 232-241. Coconut Island, O'ahu, Hawai'i. Pacific Science. 37: 87-107. 
563 Russel D.J., Balazs G.H. 1994. Colonization by the alien marine alga Hypnea musciformis

564 (Wulfen) J.Ag.(Rhodophyta: Gigartinales) in the Hawaiian islands and its utilization by

565 the green turtle, Chelonia mydas L. Aquatic Botany 47 (1): 53-60

566 Russel D.J., Balazs G.H. 2009. Dietary Shifts by Green Turtles (Chelonia mydas) in Kāne'ohe

567 Bay Region of the Hawaiian Islands: A 28-Year Study. Pacific Science. 63: 181-192.

568 Sandin S.A., Walsh S.M., Jackson J.B.C. 2010. Trophic Cascades: Predators, Prey, and the

569 Changing Dynamics of Nature. Island Press. 71-90.

570 Seymour S., Paul N.A., Dworjanyn S.A., de Nys R. 2013. Feeding preference and performance

571 in the tropical sea urchin Tripneustes gratilla. Aquaculture. 400-401: 6-13.

572 Sherwood A. R., Kurihara A., Conklin K. Y., Sauvage T., Presting G. G. 2010. The Hawaiian Rhodophyta Biodiversity Survey (2006-2010): a summary of principal findings. $B M C$

574 plant biology 10(1): 258 .

575 Simberloff D., Stiling P. 1996. How risky is biological control? Ecology 77 (7): 1965-1974.

576 Simberloff D., Dayan T., Jones C., Ogura G. 2000. Character Displacement and Release in the

577 Small Indian Mongoose, Herpestes javanicus. Ecology 81 (8): 2086-2099.

578 Smith J. E., Hunter C. L., Smith C. M. 2002. Distribution and reproductive characteristics of nonindigenous and invasive marine algae in the Hawaiian Islands. Pacific Science 56(3):

580 299-315.

581 Smith J.E., Hunter C.L., Conklin E.J., Most R., Sauvage T., Squair C., Smith C.M. 2004.

582 Ecology of the Invasive Red Alga Gracilaria salicornia (Rhodophyta) on O'ahu, Hawai'i.

$583 \quad$ Pacific Science 58: 325-343.

584 Sterner R.W., Hessen D.O. 1994. Algal nutrient limitation and the nutrition of aquatic

585 herbivores. Annual review of Ecology and Systematics 1-29. 
586 Stimson J., Cunha T., Philippoff J. 2007. Food preference and related behavior of the browsing sea urchin Tripneustes gratilla (Linnaeus) and its potential for use as a biological control agent. Mar Biol 151: 1761-1772.

Stimson J., Larned S. T., Conklin E. 2001. Effects of herbivory, nutrient levels, and introduced algae on the distribution and abundance of the invasive macroalga Dictyophaeria caevernosa in Kāne'ohe Bay, Hawai'i. Coral Reefs 19: 343-357.

Taylor R.B., Sotka E., Hay M.E. 2002. Tissue-specific induction of herbivore resistance: seaweed response to amphipod grazing. Oecologia 132 (1): 68-76.

Thomas F. 1994. Physical properties of gametes in three sea urchin species.The Journal of experimental biology 194(1): 263-284.

Thornber C., Stachowicz J.J., Gaines S. 2006. Tissue type matters: selective herbivory on different life history stages of an isomorphic alga. Ecology 87 (9): 2255-2263.

Vaïtilington D., Rasolofonirina R., Jangoux M. 2007. Feeding preferences, seasonal gut repletion indices, and diel feeding patterns of the sea urchin Tripneustes gratilla (Echinodermata: Echinoidea) on a coastal habitat off Toliara (Madagascar). Marine Biology 143: 451-458.

Valentine J. P., Edgar G. J. 2010. Impacts of a population outbreak of the urchin Tripneustes gratilla amongst Lord Howe Island coral communities. Coral Reefs 29: 399-410. Press: 159-160. 
608 Wylie C.R., Paul V.J. 1988. Feeding preferences of the surgeonfish Zebrasoma flavescens in 609 relation to chemical defenses of tropical algae. Marine Ecology Progress Series. 45: 23-

$610 \quad 32$. 
Figure 1 (on next page)

Urchin Growth

Mean weekly growth rate $(\mathrm{mm} /$ week $\pm \mathrm{SE}$ ) of Tripneustes gratilla on non-choice diets of algae (Acanthophora spicifera $n=26$, Gracilaria salicornia $n=28$, Eucheuma denticulatum $n$ $=27$, or Kappaphycus clade $B n=9$ ) reared in aquaria over a 4-week period. Note letters identify significant subsets $(p<0.05$, Tukey HSD). 





Figure 2 (on next page)

No-Choice Feeding Trials

Consumption rates ( $g /$ day $\pm \mathrm{SE}$ ) by Tripneustes gratilla during non-choice feeding trials of algae (Acanthophora spicifera, Gracilaria Salicornia, Eucheuma denticulatum, or Kappaphycus clade B). A) Small. B) Medium. C) Large. Note letters identify significant subsets $(p<0.05$ Tukey HSD post-hoc pairwise comparison). For each diet of each size cohort $n=4$. 


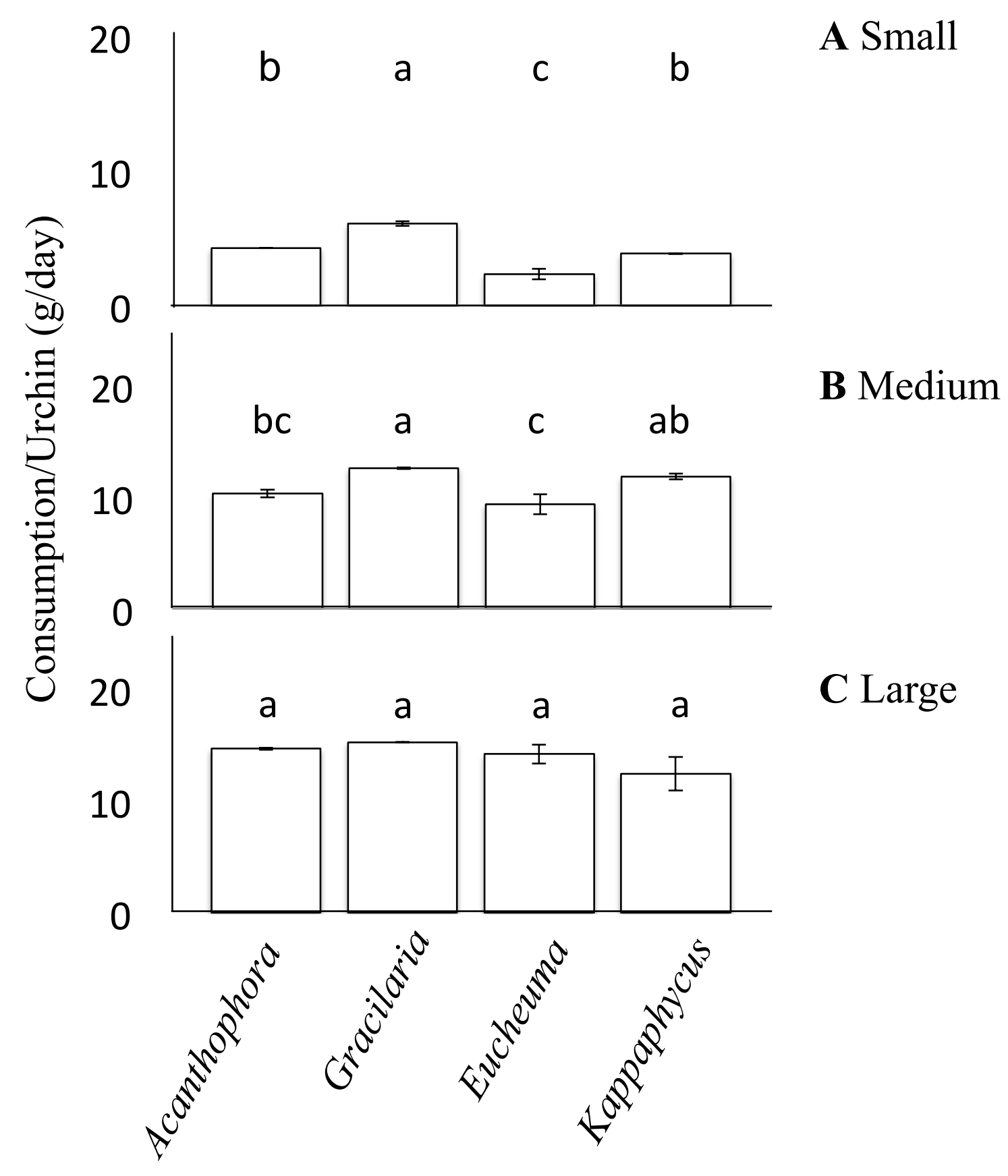


Figure 3 (on next page)

Choice Feeding Trials

Consumption rates ( $g /$ day $\pm \mathrm{SE}$ ) of Tripneustes gratilla during three choice feeding trials of algae (Acanthophora spicifera, Gracilaria Salicornia, Eucheuma denticulatum, and Kappaphycus clade B). A) Small, $n=6$. B) Medium, $n=10$. C) Large, $n=11$. 


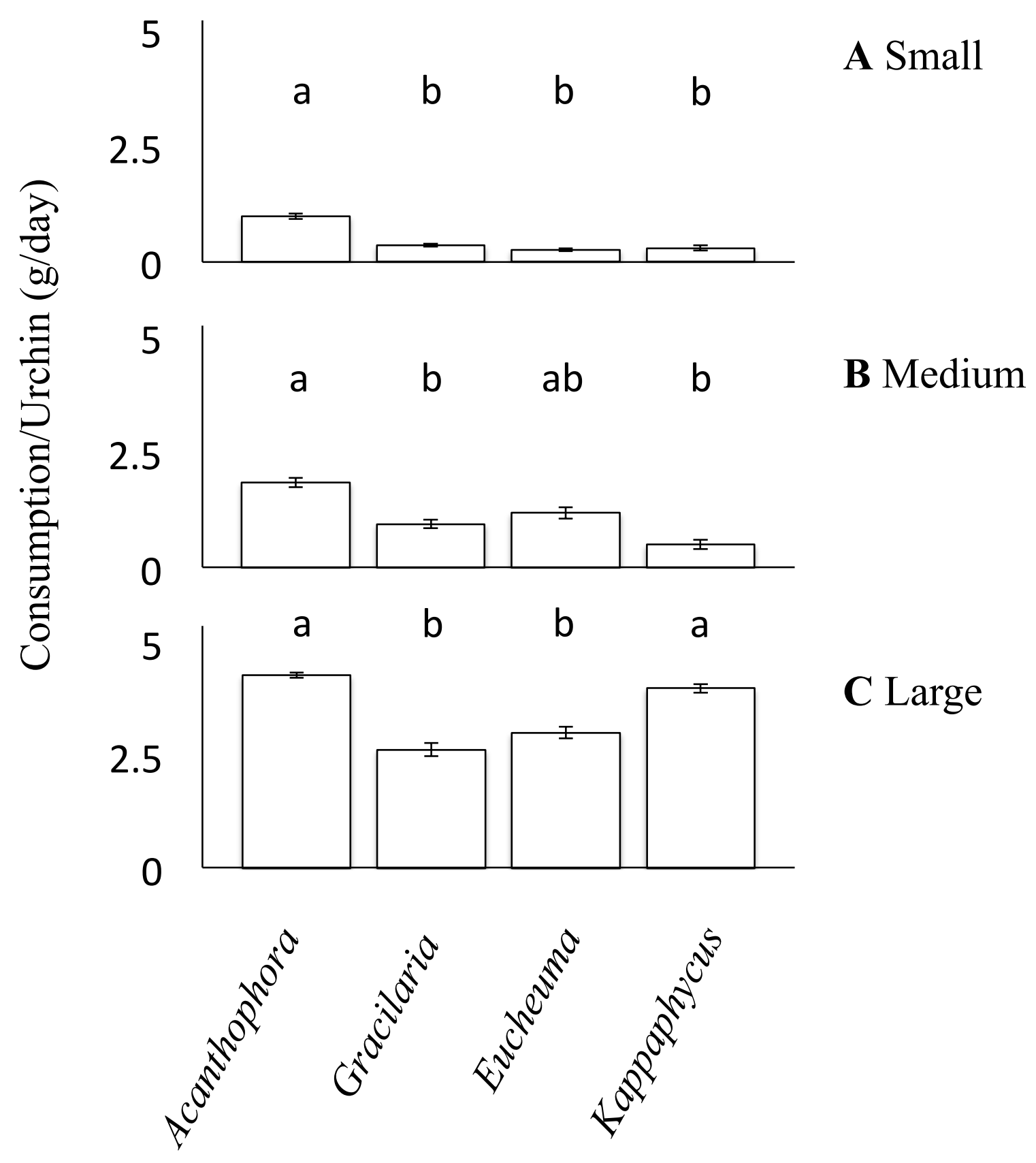


Figure 4 (on next page)

Caged Urchin Survivorship

Survivorship (\%) curves reported for urchins deployed in open and closed cages in various underwater habitats for a month. A) Reef. B) Lagoon. C) Reef Slope. 251 urchins we used across 6 sites. 
PeerJ Reviewing Manuscript

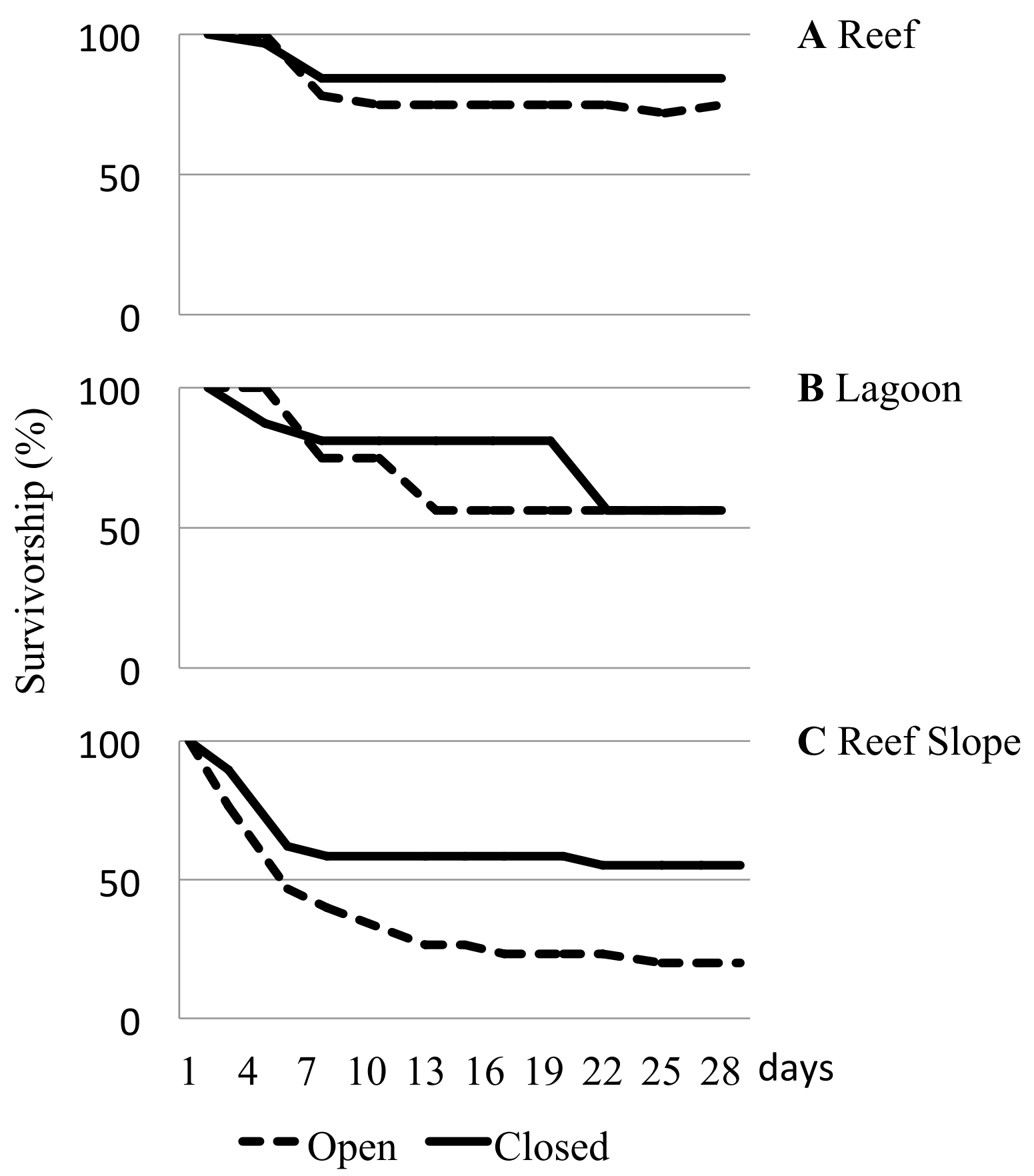


Table $\mathbf{1}$ (on next page)

Analysis of the Kaplan-Meier Survivorship curves for the Urchin Caging Experiment

A comparison of survivorship distributions between open and closed cages placed in the lagoon, the reef flat and the reef slope. 


\begin{tabular}{|c|c|c|c|c|c|c|c|}
\hline & & \multirow{2}{*}{$d f$} & \multicolumn{2}{|c|}{ Log rank } & \multicolumn{2}{|c|}{ Wilcoxon } & \multirow{2}{*}{ Verdict } \\
\hline & & & Statistic & $P$ & Statistic & $P$ & \\
\hline I. Between all treatments & & 5 & 47.15 & $<0.0001$ & 41.36 & $<0.0001$ & \\
\hline \multirow[t]{4}{*}{ II. Between open cages } & & 2 & 38.62 & $<0.0001$ & 33.59 & $<0.0001$ & \\
\hline & $\mathrm{R}$ vs $\mathrm{L}$ & 1 & 4.43 & 0.0352 & 3.17 & 0.0750 & $\mathrm{R} \geq \mathrm{L}$ \\
\hline & $\mathrm{R}$ vs $\mathrm{S}$ & 1 & 37.79 & $<0.0001$ & 32.66 & $<0.0001$ & $\mathrm{R}>\mathrm{S}$ \\
\hline & S vs L & 1 & 13.01 & 0.0003 & 12.06 & 0.0005 & $\mathrm{~L}>\mathrm{S}$ \\
\hline \multirow[t]{4}{*}{ III. Between closed cages } & & 2 & 6.73 & 0.0346 & 6.16 & 0.0460 & \\
\hline & $\mathrm{R}$ vs $\mathrm{L}$ & 1 & 4.08 & 0.0434 & 3.62 & 0.0571 & $\mathrm{R} \geq \mathrm{L}$ \\
\hline & $\mathrm{R}$ vs $\mathrm{S}$ & 1 & 6.13 & 0.0133 & 5.73 & 0.0166 & $\mathrm{R}>\mathrm{S}$ \\
\hline & S vs L & 1 & 0.05 & 0.8315 & 0.15 & 0.6959 & ns \\
\hline
\end{tabular}

Abbreviations: $\mathrm{R}=$ reef flat, $\mathrm{S}=$ reef slope, $\mathrm{L}=$ lagoon, $\mathrm{ns}=$ not significant. 